\title{
Searching For Influenza Virus In Upper Respiratory System Samples of Patients From Our Region
}

\section{Yöremizde Gribal Enfeksiyonlu Hastalarin Üst Solunum Yolu Örneklerinde Influenza Virus Arastirilmasi}

\section{Özgür Çelebi ${ }^{\star}$, Ahmet Ayyıldız}

Atatürk University Faculty of Medicine Department of Clinical Microbiology, Erzurum

\begin{abstract}
Objectives: In this study, we have planned to evaluate the frequency of Influenza virus in our region and estimate Influenza virus prevalence using Immune Fluorescent Antibody (IFA) technique.

Materials and Methods: Nasopharyngeal swab samples were included in our study Simultaneously, the patients giving samples were asked if they had been vaccinated against flu in that year. The samples identified as Influenza in our study were included in subtyping research using Real Time PCR. And Influenza virus prevelance using Immune Fluorescent Antibody (IFA) technique is identified.

Results: At the end of this study, $4(2.4 \%)$ of all patients were detected with RSV $16(9.8 \%)$ with Influenza A, and $1(1.1 \%)$ with H5N1. 2 of the adults $(2.7 \%)$ were RSV positive and $7(9.4 \%)$ of them were Influenza A-positive. In this study Influenza B was not identified in any of the patients. There was not any significant difference between the test results of those vaccinated and not vaccinated; between children and adults, or between males and females.

Conclusions: Influenza is an acute infection characterised with rapid onset of fever, fatigue, headache and myalgia. It is a disease that limits itself and the signs and symptoms fade, unless there ara any coplications. Epidemic Influenza that cirises at spesific periods is mostly caused by Influenza A and B subtypes. Subtype C, causing epidemies rarely is seen as a masked infection where no signs or symptoms are present, or as a mild disease in children. In the light of above introduction. Influenzae A,B Infection rates should be investigated periodically.
\end{abstract}

Key Words: Flu, Influenza, IFA

\begin{abstract}
ÖZET
Amaç: Bu çalışmada bölgemizde İnfluenza virüs sıklığını değerlendirmeyi ve İnfluenza virüs prevelansın1 İmmün Floresan Antikor (IFA) tekniği ile belirlemeyi planladık. Gereç ve Yöntem: Çalışmamıza nazofarengeal sürüntü örnekleri dahil edildi. Eş zamanlı olarak örnek veren hastalara o yıl grip aş1sı olup olmadıkları soruldu.Çalışmamızda İnfluenza olarak belirlenen ö rnekler Real Time PCR kullanılarak alt tipleme araştırmasına dahil edildi. Influenza virus prevelansı ise Immune Fluorescent Antibody (IFA) tekniği kullanılarak belirlendi.

Bulgular: Çalışmamızda tüm hastaların 4'ü (\% 2.4) RSV, 16's1 (\% 9.8) Influenza A ve 1'i (\% 1.1) H5N1 olarak tespit edildi. Yetişkinlerin 2'si (\% 2.7) RSV pozitif, 7'si (\% 9.4) İnfluenza-A pozitifti. Bu çalışmada İnfluenza B hiçbir hastada tespit edilmemiştir. Aş1 olan - aşı yaptırmayanlar arasında çocuklar- yetişkinlerde erkek ve kadın hastaların test sonuçları arasında anlamlı bir fark yoktu.

Sonuç: Influenza, hızlı başlayan ateş, yorgunluk, baş ağrısı ve miyalji ile karakterize akut bir enfeksiyondur. Herhangi bir komplikasyon olmadıkça kendini sınırlayan ve belirti ve semptomları kaybolan bir hastalıktır. Belirli dönemlerde ortaya çıkan epidemik influenza, çoğunlukla Influenza A ve B alt tiplerinden kaynaklanmaktadır. Nadiren salgınlara neden olan alt tip C, hiçbir belirti veya semptomun olmadığı maskeli enfeksiyon veya çocuklarda hafif bir hastalık olarak görülür. Yukarıdaki tanıtım 1şı̆̆ında, Influenzae A, B Enfeksiyon oranları periyodik olarak araştırılmalıdır.
\end{abstract}

Anahtar Kelimeler: Grip, Influenza, IFA 


\section{Introduction}

Upper Respiratory System Infections are the most common diseases that affect public health. Majority of these diseases lead to significant labour loss although they are not life-threatening. Even though causes of the mentioned diseases vary, viruses make up most of them. (1-3)

More than 200 viruses causing respiratory system infections are identified up to date. However, all of these viruses do not lead to disease at the same frequency, especially influenza viruses ( $\mathrm{A}$ and $\mathrm{B}$ subtypes), adenoviruses, parainfluenza 1,2 ve 3 viruses and Respiratory Syncytial virus (RSV) are responsible for most of the diseases that have a serious course in adults as well as children (2-4). While these pathogens may also lead to nosocomial infections, they are significant causes of morbidity and mortality in immunodeficient patients. The definitive diagnosis and efficient treatment of these clinically alike and mostly mistaken diseases are possible through detection and identification of the agent (5).

Currently, three main methods are used in the laboratory for diagnosing these diseases. Those are: Identification of the virus itself or its antigens in the infectious material; virus isolation via cell culture and serologically antibody detection. In the recent years, molecular methods have started to be used in this field as well (6-8).

Each of these techniques have specific advantages and disadvantages, and these factors as well as laboratory needs are considered for deciding which of them should be used. Antigen identification techniques such as direct immunofluorescent and rapid tests are carried out in first-line healthcare facilites where drug usage and infection control is an issue, therefore early diagnosis is essential. In this case, virus isolation and detailed antigenic information isn't needed, what matters is the test's specifity and sensitivity to be high (9).

On the other hand, while treating upper respiratory system infections, it is chosen to use antibiotics before laboratory research and identifying the agent thoroughly. This situation doesnt favor the treatment, has a negative impact on the country's economy and accelarates the formation of antibiotic-resistant strains. Considering such cases, evidence based medical applications should be regarded for treatment of upper respiratory system infections (9).

In humans, researches carried out to identify the viruses causing many acute, chronic, latent and persistent infections, are relatively challenging and costly compared to other microorganisms. $(8,9)$

In the last six years at the end of XX. century and the beginning of XXI. century, when microbiological research rapidly developed, studies and scientific research on diagnosis and treatment of viral diseases have developed at a fascinating pace. (9)

In this study, we aimed to identify the most common viral pathogens found in the nasopharynx swab samples of patients applying with symptoms of upper respiratory system infection, using IFAT technique and search how frequently these agents are present in our region.

\section{Materials and Method}

Nasopharyngeal swab samples were included in our study, that were collected from 164 patients being treated for the flu at inpatient health centers in Erzurum. In order to gather nasopharyngeal swab samples from patients applying to hospital, rayon swabs with tips covered in cotton were inserted in the patients' nose, held still for 2-3 seconds for the cotton to absorb nasal secretions, then gently rotated and removed. Simultaneously, the patients giving samples were asked if they had been vaccinated against flu in that year. The samples taken were immediately put into the viral transport medium and kept tightly closed in $-20^{\prime} \mathrm{C}$ temperature, until the time of identification. The kits from Biotrin firm, prepared appropriately for IFA method were used to detect viral respiratory pathogens' antigens on these clinical samples kept in $-20^{\prime} \mathrm{C}$.

At the end of the study, under the fluorescent microscope: nuclear and/or cytoplasmic bright green fluorescent image was evaluated as Influenza A and/or B.

During the time this study was carried out, avian influenza pandemic was present in Turkey and all the other countries. The samples identified as Influenza in our study were included in subtyping research using Real Time PCR.

Ethical Approval: There was no requirement of ethical approval form in the official protocol, in 2008.

\section{Results}

74 adults, 90 children and in total 164 patients being treated in hospitals in Erzurum were included in this study. $47(52.2 \%)$ of the children were male, and $43(47.8 \%)$ were female. 29 
Table 1. Distribution of Patients In Terms of Age and Gender

\begin{tabular}{lccc}
\hline & Male & Female & Total \\
\hline Ages $0-1$ & 0 & 1 & 1 \\
Ages $2-5$ & 17 & 7 & 24 \\
Ages $6-10$ & 12 & 13 & 25 \\
Ages $11-15$ & 18 & 22 & 40 \\
Subtotal for Children & $47(52.2 \%)$ & $43(47.8 \%)$ & 90 \\
Ages $15-40$ & 26 & 40 & 66 \\
Ages $40-65$ & 3 & 4 & 7 \\
Ages over 65 & 0 & 1 & 1 \\
Subtotal for Adults & $29(39.2 \%)$ & $45(60.8 \%)$ & 74 \\
Total & $76(46.3 \%)$ & $88(53.7 \%)$ & 164 \\
\hline
\end{tabular}

Table 2. Distribution of Patients In Terms of Cities

\begin{tabular}{lcccc}
\hline & Male & Female & Total & $\%$ \\
\hline Ağr1 & 18 & 26 & 44 & 26.8 \\
Ardahan & 2 & - & 2 & 1.2 \\
Bayburt & 2 & 2 & 4 & 2.5 \\
Erzincan & 3 & 5 & 8 & 4.8 \\
Iğdır & 9 & 11 & 20 & 12.2 \\
Kars & 5 & 3 & 8 & 4.9 \\
Mus & 7 & 7 & 14 & 8.6 \\
Erzurum & 30 & 34 & 64 & 39.0 \\
Toplam & 76 & 88 & 164 & 100 \\
\hline
\end{tabular}

(39.2\%) of the adults, were male, and 45 ' $\mathrm{i}(60.8 \%)$ were female. The distribution of the cases in terms of age group and gender are displayed on table 1, and the city they are in are displayed on table 2. The patients taking part in the study were asked if they had been vaccinated against flu during the year or not and the results are displayed on table 3.

$17(10.4 \%)$ of the patients were found to be positive for Influenza A. A child of age between 1-5 years was found to be positive for H5N1. Distribution of the viral pathogens amongst children and adults is displayed on table 4 and the cities in which they are present are displayed on table 5 Patients from any other city were not found to be Influenza-positive.

During the time this study was carried out, avian influenza pandemic was present in Turkey and all the other countries. The samples identified as Influenza in our study were included in subtyping research using Real Time PCR and only 1 sample out of these was found to be avian Influenzapositive.

\section{Discussion}

The most important feature of the Influenza A virus due to it's problematic causes in public health and economical conditions; the subgroups spesific for different types are open to exchange genetic materials. If a new virus takes a genetic code from a human-specific virus, it can gain a feature to spread among humans. The genetic structure and the antigenic alteration due to this genetic structre cause some serious problems in public health. (10-12)

According to the results of the rapid antigen tests which were performed on 100 patients who applied to Anatolia Medical Center in Kocaeli, between Semptember 2006 and March 2007, influenza antigen was detected on 24 patients $(24 \%), 2$ of them was detected as influenza B $(8.5 \%), 22$ of them was detected as influenza A $(91.5 \%)$. (9) When our study is compared to this study, we find out that our results are in lower levels. We can explain this situation according to procedure of the test or the affinity between antibody of the test kits and the virus' genetic structure. 
Çelebi ve Ayyıldız / Influenza Virus In Upper Respiratory System

Table 3. Distribution of Patients In Terms of Vaccine Application

\begin{tabular}{lcccc}
\hline & Children & Adults & Total & $\%$ \\
\hline Vaccinated & - & 14 & 14 & 8.5 \\
Not Vaccinated & 90 & 60 & 150 & 91.5 \\
Total & 90 & 74 & 164 & 100 \\
\hline
\end{tabular}

Table 4. Distribution of Viral Pathogens In Terms of Ages and Gender

\begin{tabular}{lcccc}
\hline & \multicolumn{2}{c}{ Influenza A } & \multicolumn{2}{c}{ H5N1 } \\
\hline Ages & Male & Female & Male & Female \\
\hline $0-1$ & 0 & 0 & 0 & 0 \\
$2-5$ & 3 & 1 & 1 & \\
$6-10$ & 2 & 2 & & \\
$11-15$ & 0 & 1 & & \\
$16-40$ & 2 & 5 & & \\
$41-65$ & 0 & 0 & & \\
$66+$ & 0 & 0 & 1 & 0 \\
Toplam & 7 & 9 & & \\
\hline
\end{tabular}

Table 5. Distribution of Viral Pathogens Amongst Cities

\begin{tabular}{lccccc}
\hline & \multicolumn{2}{c}{ İnfluenza A } & & H5N1 & Total \\
\hline & Male & Female & Male & Female & \\
\hline Ağr1 & 2 & 1 & 1 & 0 & 4 \\
Iğdır & 0 & 1 & 0 & 0 & 1 \\
Muş & 1 & 0 & 0 & 0 & 1 \\
Erzurum & 4 & 7 & 0 & 0 & 11 \\
Toplam & 7 & 9 & 0 & 0 & 17 \\
\hline
\end{tabular}

Önlen and his friends analyzed 90 children's levels of $\operatorname{IgG}$ and $\operatorname{IgM}$, age differs from 0 to 15 , with the symptomes of high fevered upper airway tract infections caused suspiciously by Influenza A and Influenza B in Antakya; Influenza A IgG was detected in 3 of 48 girls $(6.25 \%)$ and 2 of 42 boys $(4.8 \%)$ while Influenza B $\operatorname{IgG}$ was detected in 6 girls $(12.5 \%)$ and 11 boys $(26.2 \%)$. In total, Influenza A IgG seropositivity was 5.6\% (5/90), while Influenza B IgG seropositivity was $18.9 \%$ (17/90). IgM antiobodies weren't detected in any Influenza A and Influenza B cases. (13) In our study, seropositivity of Influenza A was 9,8\% $(16 / 164)$ while the seropositivity of Influenza B wasn't able to be detected. Even though the results of the study in Antakya may seem similar to our study, since the experimental methods are different (we used IFA, Önlen and his friends used ELISA), the smiliarity between those results is open to questioning.

The viral infections of the airway tracts are common in our country just like in the other countries and these infections may cause different symptomes in different age groups. There are intense studies about influenza virus, parainfluenza virus, adenovirus and respiratory syncitial virus which are the most common agents of the airway tract infections $(14,15)$.

Yilmaz and his friends (14) studied randomized 44 children (12-59 months old) and 48 adults in influenza season, in Ankara, and the 29 children $(65 \%)$ detected as Influenza A IgG positive, since 2 of the 44 children $(4.5 \%)$ detected as both influenza A virus IgG and IgM. It was stated that any of the children wasn't detected as positive on Influenza $\operatorname{IgA}$ in serum. The 8 children $(18.1 \%)$ detected as Influenza B IgG positive, since 5 of the 44 children $(11.3 \%)$ detected as both influenza $\mathrm{B}$ virus $\operatorname{IgG}$ and $\operatorname{IgM}$ positive. It is also stated that 1 case $(2 \%)$ was observed as Influenza B IgG, IgM and $\operatorname{IgA}$ positive. The 38 adults $(79.16 \%)$ detected as Influenza A $\operatorname{IgG}$ positive, since 3 of the 48 adults $(6.25 \%)$ detected as both Influenza A IgG and IgM positive. On the other side 3 of the 48 
adults observed as Influenza A IgM positive, 16 of them $(33.33 \%)$ were both $\operatorname{IgM}$ and $\operatorname{IgG}$ positive, and the 13 of the 48 adults $(27,08 \%)$ were detected as Influenza B $\operatorname{IgG}$ positive. When we analyze the study of Yilmaz and his friends, we observe similarities between their study and our study about the IgM antibodies against Influenza viruses. Also, when the national and international results are analyzed, it can be understood that the titers of $\operatorname{IgG}$ against Influenza viruses are in high levels. When the Influenza IgG focused epidemiological studies are observed, 100\% seropositivity must be assessed as normal. If the influenza outbreaks were seen in the same ratios without antigenic shift or antigenic drift, the tests would have showed 100\% positivity for IgG levels. Because almost everyone has been enfected by the influenza virus. The reason why our studies don't show $100 \% \operatorname{IgG}$ positivity is our antigens only react with one year old antibodies utmost, they don't react with older antibodies or even if they do, they may show cross-reactivity.

In studies that focused on our country, there is not any differences among years. In the matter of compering, results of the recent studies and the result of the previous studies, which were analyzed 5 -years periodically, also don't show any significant differences. $(14,15)$

Yilmaz and his friends' study which is known as "The research of the atypical agents in airway tract infections via IFA method" showed the ratio of Influenza $A$ virus infection as $4, \%$, the ratio of Influenza B virus infection as $45.8 \%$, in 2002, Trabzon. (16) On the otherside, Yarkin and his friends' study which is known as "The incidence of the viral lower airway tract infection in pediatric population" showed the ratio of Influenza A virus infection as $2.4 \%$, the ratio of Influenza B virus infection as $9.9 \%$. (17)

Influenza virus, as one of the viruses which cause airway tract infecitions, has an important place due to its capacity of causing an epidemia or/and a pandemia and due to its pulmonary complications which they show mortal course. The epidemics of influenza mostly seen between December and April in North Hemisphere. A surveillance research of influenza virus' in between 2002-2006 showed that the infection mainly seen in January in Turkey, according to the isolation amount of the collected samples were utmost in January (18-21).

Influenza A (H3N2) was the most common virus that has been reported between in November-May 2004-2006, worlwide. Alongside with H3N2,
Influenza A (H1N1) and Influenza B also has been seen, even if in the small amounts. The most common virus of the recent years is A / H3N2, A / Fujian / 411 / 02- Like ve A / Wyoming / 03 / 2003. Influenza A (H1N1) / New Caledonia / 20 / 99 was reported poorly. Influenza B is detected as two different antigenic types; B / Yamagata / 16 / 88 and B / Victoria / 2 / 87 (22-24).

Çelikbaş and his friends (27) reported the ratio of Influenza A as $4.5 \%$ and the ratio of Influenza B also as $4.5 \%$ in their studies, in 2008 . When the studies which are performed in Turkey and in some other countries are compared, the ratios can be observed as similar (25-27).

In our study, 14 of the patients were vaccinated while 150 of them were not. The vaccinated patients were adults and 2 of them (12.5\%) were infeceted by Influenza A virus. The reason why those patients were infected by the virus even though they were vacinated is, they were vaccinated in inappropriate time or, the strain that causes the infection and the strain that the vaccine includes, were different. As a result, the vaccines must be prepared by the instructions which are given by WHO and the people must be vaccinated before the influenza season.

The signs and symptoms of influenza which is commonly seen globally just like in our country, may differ from mild to severe. Even though there are so many studies targeting the Influenza virus, there hasn't been any decrease in the number and in the severity of the infection. The virus renovates itself and keeps infecting the people with the same number and the same severity as if competing with the new procedures and new methods suggested by studies, researches.

The new studies that are performed by our country and also by the world, show that these kind of studies must be repeatedly performed and new vaccines must be developed for the new strains of the virus. The new antivirals must be developed or new additions must be arrenged for the existing medicines' root structure in case of the virus gain resistancy against to present antivirals. Maybe the most improtant step is to research the genetic structure of the virus restrospectively and with the help of the information that is collected by the previous studies, we can foresee and calculate the genetic alterations of the virus and we can prepare new vaccines for any possible genetic structure. 


\section{References}

1. Kobasa D, Takada A, Shinya K, Hatta M, Halfmann P, Theriault S, et al. Enhanced Virulence of influenza A viruses with the haemagglutinin of the 1918 pandemic virus. Nature 2004; 431(7009): 703-707.

2. Dharmage SC, Rajapaksa IC, Fernando DN. Risk factors of lower respiratory tract infections in children under five yers of age. Southeast Asian J Trop Med Public Health 1996; 27: 107-110.

3. Gruber WB. Bronchiolitis, In: Long SS, Pickering LK, Prober CG, eds. Pediatric Infection Diseases 1st ed. New York: Churchill Livingstone 1997; 246-250.

4. Bright RA, Shay DK, Shu B, Cox NJ, Klimov AI. Amantadine resistance among influenza $A$ viruses isolated early during the 2005-2006. İnfluenza season in the United State. JAMA 2006; 295: 891-894.

5. Nicholson KG, Wood JM, Zambon M. Influenza. Lancet 2003; 362: 1733-1745.

6. Johnston SL, Siegel CS. Evolution of direct immuno fluorescense, enzyme immunoassay centrifugation culture and conventional culture for the detection of respiratory synctial virus. J Clin. Microbiol 1990; 28: 2394.

7. Govorkova EA, Leneva IA, Goloubeva OG, Bush K, Webster RG. Comparison of efficasies RWJ- 270201, Zanamivir and oseltamivir againts H5N1, H9N2 and other influenza viruses. Antimicrob Agents Chemother 2001; 45: 2723-2732.

8. Rota S, Solunum Sinsityal Virus. In: Mutlu G, imir T, Cengiz AT, Ustaçelebi S, Tümbay E, Mete Ö eds. Temel ve Klinik Mikrobiyoloji. Günes Kitabevi, Ankara 1999; 941-43.

9. Özdamar M, Türkoğlu S, Hakko E, Tahmaz EF. İstanbul ve Kocaeli'nde influenza prevalansının hizlı antijen testi ile belirlenmesi. Ankem Dergisi, 2007; 21:51-52.

10. Akan E, Ortomyxoviridae, Genel ve Özel Viroloji. Türkiye Klinikleri yayınevi, 2.Baskı, Ankara 1996; 333352.

11. Ustaçelebi S. Genel Viroloji. Ankara, 1991: 31-32.

12. David T. Kingsburg, Gerald E. Wagner. Microbiology. 2 nd ed. New York 1990; 251-252.

13. Önlen $Y$, Duran N, Savas L, İncecik F, Tas S. Antakya'da 0-15 yasları arasındaki ÜSYE süpheli çocuklarda influenza A ve influenza B virusu seroprevalans1. Klimik Kongre Kitab1 2005; 21: 315.

14. Yilmaz N, Yildırım R, Artuk C. Investigation of influenza $A$ and $B$ virus seroprevalence among children and adults. Microbiol Bült 1998; 32: 329-335.
15. Yamazhan T, Dereli D, Ertem E, Serter D. 1995-1996 Kıs Mevsiminde, hücre kültürü yöntemi ile bölgemizde saptanan adenovirus, solunum sinsityal virusu ve parainfluenza virusu enfeksiyonları. 27.Türk Mikrobiyoloji Kongresi Kitabı Antalya 1998: 58.

16. Yılmaz G, Çaylan R, Kostakoğlu U, Sucu N, Köksal İ. Solunum yolu infeksiyonların da IFA yöntemi ile atipik ajanların arastırılması. 30.Türk Mikrobiyoloji Kongresi Kitab1, Antalya 2002; 379.

17. Yarkın F, Alhan E, Kibar F, Karabay A, Köksal F. Pediatrik populasyonunda viral alt solunum yolu enfeksiyonlarının insidans1. 25.Türk Mikrobiyoloji Kongresi Kitab1, Antalya 1994; 225.

18. Treanor JJ. İnfluenza virus. Mandell GL, Mennett JE, Dolin R, eds. Principles and Practice of Infectious Disease. 5 th ed. Philadelphia: Chuchill Livingstone 2000; 1823-1849.

19. Arslan S, Önal A. Türkiyede 2002-2003 Kis mevsiminde İnfluenza virusu sürveyans arastırması. http:// www.gribeson.son/ovep images/Flusurveyans 2002-2003 Turkey.pdf.

20. Leblebicioğlu H. İnfluenza: Klinik Tanı ve Tedavi İnfeksiyon Hastalıklar1 Serisi 2001; 4: 174-6.

21. Kaygusuz S, Köksal İ. İnvestigation of atypical bacteria and virüs antigens in respiratory tract infections by use of immunofluorescence metod. Jpn. J. Infect Dis 41 2004; 57: 33-6.

22. CDC. Prevention and control of Influenza: recommendation of the Advisory Commitee on Immunization Practices (ACIP). MMWR 2004; 53 (No.RR-6).

23. CDC. Update: İnfluenza Activity-United States and Worldwide, May-October 2004. MMWR 2004; 53: 993-995.

24. CDC, 2003-2004 İnfluenza (flu) Weekly report İnfluenza season summary http://www.cdc.gov/flu/weekly//weeklyarchives 2004-2005/weekly 48.htm

25. WHO Collaborating Centre for Reference and Research on İnfluenza, London: Agust 2003 to July 2004; Report

26. Weekly Epidemiological Record, 14 March 2003. 78 th Year, No.11, 2003: 78,73.80. http:// www. Who.int/wer.

27. Çelikbas AK, Yılmaz N, Ulu A, Ergönül Ö, Dokuzoğuz B, Kara S, Toprak S. Üst solunum yolu infeksiyonlarında viral etkenlerin arastırılması. İnfeksiyon Dergisi (Turkish Journal of Infection) 2005; 19(3): 377-380. 